\title{
Bacillus 属細菌による水ようかんの離水
}

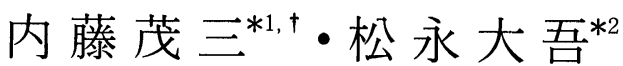 \\ (*1愛知県食品工業技術センター, *2愛知工業大学 $)$ \\ （受付 平成 13 年 7 月 5 日） \\ （受理 平成 14 年 9 月 28 日）
}

\section{Syneresis of Mizu-yokan (Soft Bean Jam Jelly) by Bacillus spp.}

\author{
Shigezo NAito ${ }^{* 1, \dagger}$ and Daigo MatsunagA ${ }^{* 2}$ \\ ${ }^{* 1}$ Food Research Institute, Aichi Prefectural Government, \\ Nishi-ku, Nagoya 451-0083; ${ }^{\dagger}$ Corresponding author) \\ ${ }^{(* 2}$ Aichi Institute of Technology, Yagusa-cho, Toyoda 451-0356)
}

\begin{abstract}
Physicochemical and microbiological investigation for syneresis of Mizu-yokan (Soft bean jam) revealed the conversion of saccharide in the components by a specific bacteria, $B a$ cillus subtilis etc.; Mizu-yokan with syneresis over 30\% was accompanied by the increases of glucose, fructose, maltose and maltotriose, and the formation of levan from sucrose in the components. These phenomena were also observed in the Mizu-yokan-inoculated cells of Bacillus spp. isolated from the spoiled samples, or in jam added to culture broth from which bacterial cells had been excluded by membrane filter, suggesting that the marked syneresis of Mizu-yokan derives from the action of Bacillus spp., bacteria in the raw materials.
\end{abstract}

Key words: Syneresis, Mizu-yokan (Soft bean jam), Sucrose, Levan, Bacillus subtilis

緒言

ようかんには練りようかんと水ようかんのほかに蒸し ようかんがある．練りようかんはあん，しょ糖，寒天を よく溶かし込んで十分時間をかけて水分 $25 \%$ 前後まで 炊き上げ，練り上げるものである。これに対して水よう かんはしょ糖液に生あんを加えて加熱し, あらかじめ溶 解させた寒天液を添加後沸騰させて短時間で惹詰め上 げ，水分 $50 \%$ 前後としたあのである．高水分のため水 ようかんを保存すると, 水が表面ににじみでて水滴とな る.これは寒天が収縮して包合していた遊離水を押し出 してくるためである. 湯殺菌水ようかんでは正常製品で あ離水が必ず生じており, 離水率は 3〜 5\% であるが, 肉眼的には全く変化か認められない. しかし, 離水率が $20 \%$ 以上になると肉眼的にも変化が認められ，この際， 必ずBacillus 属細菌が検出されることおよび無殺菌水 ようかんや加熱不良水ようかんのように微生物が残存し ているおそれがある場合, 離水率が $30 \%$ 以上になるこ とが経験的に知られていた，著者の一人は，水ようかん の微生物変敗について, 变敗原因菌の分離・同定, さら

\footnotetext{
†連絡先

*1 要451-0083 名古屋市西区新福寺町 2-1-1

*2 ⿶470-0356 豊田市八草町八千草
}

にその分離菌，あんなどを含む原材料，製造工程のオゾ ン処理について検討を行ってきた ${ }^{9,10)}$. ここでは変敗水 ようかんで最もよく認められるBacillus 属細菌とそれ らによる離水現象について検討したので報告する.

\section{材料および方法}

\section{1. 供試試料および菌株}

愛知県下の水ようかん製造会社 3 社 $(\mathrm{A}, \mathrm{B}, \mathrm{C})$ が製造 した小倉, 練および抹茶の湯殺菌水ようかんを用いた。 微生物の分離には離水率 $20 \%$ 以上のものを用いた，以 下離水率 $20 \%$ 以上の水ようかんを離水水ようかんと し, 離水率 $5 \%$ 以下の水ようかんを正常水ようかんとし た。 供試標準菌株として Bacillus subtilis IFO 3007, B. licheniformis IFO 12107, B. stearothermophilus ATCC 12980 を用いた。

\section{2. 水ようかんの製造およひ試験方法}

試作水上うかんの基本配合は小豆生あん $200 \mathrm{~g}$ ，しょ 糖 $200 \mathrm{~g}$, 粉末寒天 $2.5 \mathrm{~g}$, 水 $250 \mathrm{~g}$, 食塩 $0.6 \mathrm{~g}$ を用い て製造し，仕上量は $560 \mathrm{~g}$ ，水分含量 $52 \%$ とした。な お，しょ糖量を変化させる場合は適宜仕上量を変化させ た。試作方法は寒天に水 $50 \mathrm{~g}$ を加えて膨潤させておき, 小豆生あんにしょ糖, 食塩および残りの水を加え, 混合 しながら約 15 分間煮沸させた。これにあらかじめ使用 
120 日食微誌 Vol. 19 No. 32002

水の一部で溶解しておいた寒天液を加えて所定の重量ま で煮詰めた後, その $67 \mathrm{~g}$ を上部直径 $6.5 \mathrm{~cm}$, 下部直径 $5.5 \mathrm{~cm}$, 高さ $2.0 \mathrm{~cm}$ のカップに充填し, 密封した. これ を容器ごと沸騰水中で 30 分間加熱し, 流水中で冷却後 製品とした. 保存試験は, $30^{\circ} \mathrm{C}$ の恒温器内で 2 週間行っ た. 分離した Bacillus 属細菌の栄養細胞の接種やその粗 酵素を添加して人工的な变敗水ようかんを試作する場合 は, 正常水ようかんの加熱後凝固する前に滅菌注射器で 1 カップ当たりそれぞれ $1 \mathrm{~m} l$ を接種および添加し，そ の穴を滅菌ゴム板で塞いだ,

\section{3. 微生物の分離・同定・計数}

微生物の分離には, 試料を殺菌済み生理食塩水に加 え, 無菌的にミキシング後, その一部を標準寒天培地 （日水製薬(株)製）上に塗抹し， $30^{\circ} \mathrm{C}, 3$ 日間培養して寒 天平板上に出現したコロニ一の形状および顕微鏡での観 察結果を勘案して単一コロニーを釣菌し， $30^{\circ} \mathrm{C}$ で培養 し，以下の実験に用いた．分離菌株の同定は「改訂版微 生物の分離之同定 $\rfloor^{3)}$ と「Bergey's Manual of Systematic Bacteriology」18) に従って行った。なお, Bacillus 属細菌の菌数は, 試料水ようかんを $95^{\circ} \mathrm{C}, 10$ 分間加熱 後上記寒天培地に塗抹し, 培養後出現したコロニーの細 菌菌体が桿菌でカタラーゼ反応陽性, かつ芽胞を形成す るグラム陽性菌をBacillus 属細菌として計数した.

\section{4. 供試菌株の細胞懸濁液およひ菌体外酵素液の調製}

分離菌株をしょ糖 $3 \%$, 酵母エキス $1 \%$ ， ポリペプト ン $0.5 \%$ 含有液体培地 $200 \mathrm{ml}$ に接種し, $30^{\circ} \mathrm{C}, 2$ 日間 $1,000 \mathrm{rpm}$, ロータリーシェイカー（トーマス科学機器 （株)製, TAL-RS12 型）で培養を行った後, 培養液を $1,500 \times g, 4^{\circ} \mathrm{C}$ で 10 分間遠心分離を行った. この際, 沈 殿物を冷却した滅菌脱イオン水で 3 回洗浄した後, 適量 の同イオン水に懸濁したものを細胞懸濁液 $\left(1.0 \times 10^{8}\right.$ $\mathrm{CFU} / \mathrm{ml})$ とした。 さらに上澄液をメンブランフィル ター（ポアサイズ $0.45 \mu \mathrm{m}$ ， ミリポア(株)製)でろ過し たすのを粗酵素液とした。なお，この粗酵素液を $100 \mathrm{~m} l$ 容三角フラスコに $20 \mathrm{ml}$ 入れて $95^{\circ} \mathrm{C}, 30$ 分間加熱失活 させたものを加熱粗酵素液とした。

\section{5. 糖類の分析}

水ようかんの糖類の分析は次のように行った. 水よう かんに 10 倍量の脱イオン水を添加してホモゲナイズ 後, そのホモゲナイズ液をメスシリンダーに 10 分間放 置して不溶物を沈殿させた。この沈殿部分を東洋ろ紙 No. 2 で除去後, 万液からさらにタンパク質を徐去する ために酶酸鉛飽和溶液（結晶酶酸鉛 $\mathrm{Pb}\left(\mathrm{CH}_{3} \mathrm{CO}_{2}\right)_{2} \cdot 3 \mathrm{H}_{2} \mathrm{O}$ (関東化学(株)製, 特級) を滴下・混合して沈殿させた。 これを再び同様のろ紙でろ過後，過剩の鉛を除去するた めにろ液にシュウ酸ナトリウム(関東化学(株)製, 特級) 粉末を少量入れ、シュウ酸鉛を沈殿させた。生じた沈殿 を同様ろ紙でろ過したものを分析用試料とした。なお， 離水液む同様に処理して試料とした。なお，試料糖質と して, しょ糖, グルコース, フラクトース, マルトース,
マルトトリオース（いずれもナカライテスク（株)製）を 用いた。

糖類の分析は, 高速液体クロマトグラフィー (HPLC, 日本分光(株)製，OL-2 型）により 2 つの方法で行った (ポンプ: PU-980, 検出器: 830-RI 示差屈折計). 方法 1: カラムは Shodex Ionpak S-802 $(8.0 \mathrm{~mm} \times 500 \mathrm{~mm}$ i.d.) (昭和電工(株)製)を用い, 移動相はイオン交換水を 溶媒として流速 $1.0 \mathrm{~m} l / \mathrm{min}$, カラム温度 $80^{\circ} \mathrm{C}$ で展開し た。この場合の最小検出感度は試料ピーク S/ノイス ピーク $\mathrm{N}=10$ の場合, しょ糖 $0.380 \mathrm{mg} / \mathrm{ml}$, グルコー ス $0.205 \mathrm{mg} / \mathrm{ml}$, フラクトース $0.330 \mathrm{mg} / \mathrm{ml}$ であっ

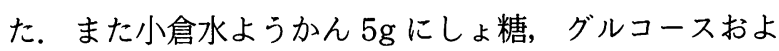
びフラクトース $200 \mathrm{mg}$ 添加した場合の回収率はそれ ぞれ $92.3 \%, 93.2 \%$ および $92.5 \%$ であった. 方法 2: 力 ラムは Finepak SIL NH2-5 (4.6 mm $\times 250 \mathrm{~mm}$ i.d.) (昭和電工(株)製）を用いてアセトニトリル：水 $=80$ ： 20 から $60: 40$ を移動相として, 流速 $0.7 \mathrm{ml} / \mathrm{min}$, カラ ム温度 $40^{\circ} \mathrm{C}$ で行った. この場合の最小検出感度は保持 時間により異なったが平均して $\mathrm{S} / \mathrm{N}=10$ の場合，しょ 糖 $0.390 \mathrm{mg} / \mathrm{ml}$, グルコース $0.230 \mathrm{mg} / \mathrm{ml}$, フラク トース $0.375 \mathrm{mg} / \mathrm{ml}$ であった。また小倉水ようかん 5 $\mathrm{g}$ にしょ糖, グルコースおよびフラクトース $200 \mathrm{mg}$ 添 加した場合の回収率はそれぞれ $91.5 \%, 92.4 \%$ および 90.5\% であった。

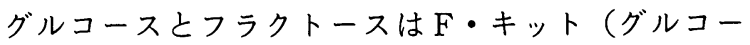
ス/フラクトース；ベーリンガー・マンハイム山之内製 薬(株)製）を用いる酵素法でそれぞれ分別定量した。

しょ糖はしょ糖含量 0.1 0.5\%になるように希釈し た糖液 $50 \mathrm{~m} l$ を $300 \mathrm{~m} l$ 容三角フラスコにとり $25 \%$ 塩 酸 $5 \mathrm{ml}$ を加え, $65^{\circ} \mathrm{C}$ の湯浴に 15 分間処理した後冷却 し，10\% 水酸化ナトリウム溶液で中和した ${ }^{11}$. こ これを $500 \mathrm{~m} l$ 容のメスフラスコに移し, 標線まで加水, 一定量 としたものについて醰素法で求めた.

全糖量はフェノール硫酸法 ${ }^{21)}$ で, 還元糖量はSomogyi-Nelson 法 ${ }^{21)}$ で求めた. Brix はデジタル屈折計 （(株）アタゴ製，RX-1000）を用いて試料品温 $20^{\circ} \mathrm{C}$ で測 定した。水分は海砂法 ${ }^{13)}$, 水分活性は, 水分活性測定装 置 (Nova Sina 社製, JEL-20 型)を用いて $25^{\circ} \mathrm{C}$ の恒温 器中で測定した.

ケトース，還元糖の検出はペーパクロマトグラフィー (PPC)により行った. 東洋万紙 No. $50(18 \times 20 \mathrm{~cm})$ を使 用し，1-ブタノールーピリジンー水 $(6: 4: 3, \mathrm{v} / \mathrm{v} / \mathrm{v})$ を展 開溶媒として用い, 上昇法により 2 重展開を行った。ケ トースの検出はフロログルシンによる方法 ${ }^{11}$, 還元糖の 検出はアルカリ性硝酸銀による浸漬法 ${ }^{11)}$ により行った. 糖類の確認のために薄層クロマトグラフィーを行った。 シリカゲル $\mathrm{G}$ を担体とし, 展開溶媒はアセトン $N$-ブタ ノール-水 $=5: 4: 1$ を用い, 発色は濃硫酸を噴霧後加熱 した. 糖類の旋光度は高速自動旋光計 (SEPA-200, （株）堀場製作所製）を用いて， $25^{\circ} \mathrm{C}$ で測定した。 
糖類の赤外吸収スペクトルは測定試料 $1 \mathrm{mg}$ を臭化力 リゥム $200 \mathrm{mg}$ に混合し，錠剂法により赤外分光光度計 （日本分光(株)製，IR-5B）で測定した．また，糖類の混 融試験はミク口融点測定装置（(株)島津製作所製, MN2 型）によって行った.

\section{6. 高分子糖類の調製 5}

しょ糖 $10 \%$ ，酵母エキス $1 \%$ を含む培地を $0.1 \mathrm{M}$ リ ン酸緩衝液で $\mathrm{pH} 7.0$ に調整後加圧加熱滅菌したもの 10 $\mathrm{m} l$ を透析チューブ内に入れて分離菌株 (B. subtilis No. 1 菌株）を 1 白菌耳接種した。このチューブをあらかじ め加圧加熱殺菌した $0.25 \%$ ポリペプトン $2 l$ の液に無 菌的につるして, $30^{\circ} \mathrm{C}, 7$ 日間培養した。培養終了後 チューブ内の培養液に脱イオン水を $100 \mathrm{ml}$ 添加した 後，遠心分離 $\left(1,500 \times g, 4^{\circ} \mathrm{C}, 10\right.$ 分間) を行った。 そ の上澄液にアセトンを加えて生じた沈殿物に $10 \mathrm{ml}$ の 脱イオン水を添加し, さらに 2 倍量のクロロホルム, $n$ アミルアルコールを加えて振とうし, 前記と同様の条件 で遠心分離した．その水層部を採り凍結乾燥して高分子 糖類画分とした．この高分子糖類のアセチル化は Lyne らの方法 ${ }^{77}$ に従い，供試高分子糖類 $1 \mathrm{~g}$ を水 $2 \mathrm{~g}$ に溶解 し, ピリジン $20 \mathrm{ml}$ を加え, 水水中で冷却しつつ無水酢 酸 $20 \mathrm{ml}$ を滴下した.これを室温で一夜放置した後, 水 水中に注入し沈殿物を得た。これをアセチル化高分子糖 類とした. イヌリンの場合も同様にして行った。

\section{7. 水ようかんの離水率およびゼリ一強度の測定}

離水率は次式にて算出した。

離水率=（製品重量一ようかん部重量） $\times 100 /$ 製品重量 ゼリ一強度の測定は万能引張圧縮試験機（Datally 社 製 401-DCS-100）により圧縮速度 $100 \mathrm{~mm} / \mathrm{min}$, チャート速度 $1,000 \mathrm{~mm} / \mathrm{min}$, ロードセレクター 100 , Gage25（フルスケール $1 \mathrm{~kg}$ )，プランジャー (円筒形) 直径 $10 \mathrm{~mm}$ の条件で測定した。

\section{実 験 結 果}

\section{1. 水ようかんの離水性状と Bacillus 属細菌数}

離水率 $20 \%$ 以上の湯殺菌水上うかんの離水状況之 Bacillus 属の菌数を測定した結果を Table 1 に示した. 抹茶水ようかんは離水率 35 $45 \%$ 之高く，ついで小倉 水ようかんが 30 40\%であったが，練水ようかんは 20〜35\% であった．正常な水ようかんはいずれも Brix 42〜 52\% であったが離水の発生により Brix 40４9\% に低下した．また，いずれの水ようかんも離水部分は Brix 42〜 48\% であった。なお今回供試した水ようかん はBrix の約 80\% が全糖量に相当した. 正常な水ようか んの水分は 43 54\% であったが， 離水により低下して $36 \sim 47 \%$, ジェリー強度は $410 \sim 515 \mathrm{~g} / \mathrm{cm}^{2}$ から 714 $\sim 1025 \mathrm{~g} / \mathrm{cm}^{2}$ に著しく増加し, 硬くなった。

湯殺菌水ようかんの Bacillus 属細菌数はいずれも $300 \mathrm{CFU} / \mathrm{ml}$ 以下であったが離水した水ようかんでは $1.1 \times 10^{5} \sim 3.6 \times 10^{6} \mathrm{CFU} / \mathrm{m} l$ が検出された。 な㧍離水

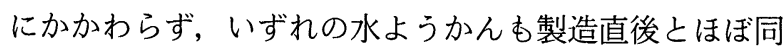
じ $\mathrm{pH}$ である 6.10〜6.25 の範囲にあった。

\section{2. 離水水ようかんの糖構成比の変化}

離水水ようかんは容器内で縮み現象を生じていた。水 分 $43 \sim 54 \%$ の水ようかんでは糖の構成比の变化に由来 する浸透圧の変化が予測された．離水水ようかんと正常 な水ようかんの糖の構成比を調べた．離水したいずれの 水ようかんともしょ糖が著しく減少し，グルコース， フ ラクトース，マルトース，マルトトリオースおよび高分 子糖類の存在が認められた． A 社製の離水率 $40 \%$ の小 倉水ようかん, 離水率 $35 \%$ の練水上うかん, 離水率 $45 \%$ の抹茶水ようかんの糖の組成比を比較した結果が Table 2 である. いずれの水ようかんも離水によりしょ 糖が正常品の 98.5 99\% から 7.0 10.5\% と著しく減 少し，グルコースが正常品の $0.2 \sim 0.5 \%$ から $40.3 \sim$ $45.7 \%$, 高分子糖類が正常品の $0.5 \sim 0.6 \%$ から $14.8 \sim$ $20.0 \%$ 之增加していた. 離水液の糖の構成比は水ようか

Table 1. Syneresis of Mizu-yokan (Soft bean jam)

\begin{tabular}{|c|c|c|c|c|c|c|c|c|c|c|}
\hline \multirow{2}{*}{$\begin{array}{c}\text { Kind of } \\
\text { Mizu-yokan }\end{array}$} & \multicolumn{2}{|c|}{ Moisture (\%) } & \multicolumn{2}{|c|}{$\begin{array}{c}\text { Rate of syneresis } \\
(\%)\end{array}$} & \multicolumn{2}{|c|}{$\operatorname{Brix}(\%)$} & \multicolumn{2}{|c|}{$\begin{array}{l}\text { Jelly extention } \\
\qquad\left(\mathrm{g} / \mathrm{cm}^{2}\right)\end{array}$} & \multicolumn{2}{|c|}{$\begin{array}{l}\text { Cells of Bacillus } \\
\text { spp. }(\mathrm{CFU} / \mathrm{m} l)\end{array}$} \\
\hline & $a^{* *}$ & $\mathrm{~b}$ & a & $\mathrm{b}$ & $\mathrm{a}$ & $\mathrm{b}$ & a & $\mathrm{b}$ & $\mathrm{a}$ & $\mathrm{b}$ \\
\hline Ogura $(\mathrm{A})^{*}$ & 54 & 52 & 3 & 40 & 50 & 48 & 510 & 980 & $300>$ & $2.1 \times 10^{6}$ \\
\hline Neri (A) & 47 & 44 & 5 & 35 & 48 & 46 & 479 & 885 & $300>$ & $1.8 \times 10^{6}$ \\
\hline Matcha (A) & 45 & 43 & 3 & 45 & 46 & 44 & 505 & 1025 & $300>$ & $3.6 \times 10^{6}$ \\
\hline Ogura (B) & 48 & 45 & 5 & 37 & 48 & 46 & 495 & 912 & $300>$ & $3.8 \times 10^{5}$ \\
\hline Neri (B) & 46 & 43 & 4 & 26 & 45 & 43 & 410 & 743 & $300>$ & $2.7 \times 10^{5}$ \\
\hline Matcha (B) & 45 & 41 & 3 & 43 & 42 & 40 & 515 & 989 & $300>$ & $2.9 \times 10^{5}$ \\
\hline Ogura $(\mathrm{C})$ & 50 & 47 & 5 & 30 & 52 & 49 & 468 & 830 & $300>$ & $5.5 \times 10^{5}$ \\
\hline Neri $(C)$ & 46 & 44 & 3 & 20 & 46 & 45 & 470 & 714 & $300>$ & $1.1 \times 10^{5}$ \\
\hline Matcha $(\mathrm{C})$ & 43 & 41 & 5 & 35 & 45 & 44 & 494 & 920 & $300>$ & $8.0 \times 10^{5}$ \\
\hline
\end{tabular}

*A, B, C: Mizu-yokan manufacturer, **a: Normal Mizu-yokan, b: Mizu-yokan with syneresis Ogura Mizu-yokan: Soft azuki-bean jam, Neri Mizuyokan: Soft ootebo-bean jam with coloring agent, Matcha Mizuyokan: Soft ootebo-bean jam with green tea 
Table 2. Saccharide composition of Mizu-yokan with syneresis produced in A factory

\begin{tabular}{|c|c|c|c|c|c|c|}
\hline \multirow{2}{*}{ Saccharide } & \multicolumn{2}{|c|}{ Ogura } & \multicolumn{2}{|c|}{ Neri } & \multicolumn{2}{|c|}{ Matcha } \\
\hline & a & $\mathrm{b}$ & a & $\mathrm{b}$ & $\mathrm{a}$ & $\mathrm{b}$ \\
\hline & $(\%)$ & $(\%)$ & $(\%)$ & $(\%)$ & $(\%)$ & $(\%)$ \\
\hline Glucose & 0.4 & 45.7 & 0.5 & 40.3 & 0.2 & 45.0 \\
\hline Fructose & 0.3 & 17.5 & 0.4 & 16.7 & 0.2 & 15.0 \\
\hline Sucrose & 98.8 & 8.5 & 98.5 & 10.5 & 99.0 & 7.0 \\
\hline Maltose & 0.0 & 7.0 & 0.0 & 6.0 & 0.0 & 6.5 \\
\hline Maltotriose & 0.0 & 3.5 & 0.0 & 3.0 & 0.0 & 3.5 \\
\hline Polysaccharide & 0.5 & 14.8 & 0.6 & 20.0 & 0.6 & 18.0 \\
\hline Unkown & 0.0 & 3.0 & 0.0 & 3.5 & 0.0 & 5.0 \\
\hline
\end{tabular}

a: Normal Mizu-yokan, b: Mizu-yokan with syneresis

Rate of syneresis: Ogura Mizu-yokan 40\%, Neri Mizu-yokan 35\%, Matcha Mizu-yokan 45\%

んとほぼ同じであった。

\section{Bacillus 属細菌による水ようかんの離水}

著者の一人は，水ようかんの膨張，離水およびネト生 成現象をレトルト製品，湯殺菌製品のいずれにも認め, それらから B. cereus, B. megaterium, B. subtilis, B. polymyxa, B. circulans および B. stearothermophilus を検出 している9).これは水ようかんの Brix が 40〜50\%であ るため,この Brix 濃度で生育可能な上記の菌が検出さ れたあのと考えられる ${ }^{9}$ ，そこで再度，前項で用いた $\mathrm{A}$ 社製の離水率が $40 \%$ で水分含量 $52 \%$ の小倉水ようか ん, $35 \%$ で水分含量 $44 \%$ の練水ようかん，45\% で水分 含量 $43 \%$ の抹茶水ようかんから Bacillus 属細菌の分 離・同定を行った。標準寒天平板培地上に生じたコロ ニーの形状およびその細胞の顕微鏡観察結果から判断 し，各水ようかんよりそれぞれ 3 タイプの Bacillus 属 細菌，小倉水ようかんでは数が最む多いNo. 1 とその 1/1,000 近い No. 2, No. 3 を，練り水ようかんならびに 抹茶水ようかんからそれぞれ最も数の多いNo. 4 と No. 7 を，さらにその 1/1,000 以下の No. 5 および 6 ， ある いはNo. 8 および 9 を分離した。これらの各水ようかん の中で最も多く検出された No. 1, No. 4, No. 7 の同定 試験結果は Table 3 に示すように, これらの 3 菌株はす べて B. subtilis と判定した。同様に他の分離菌株を同定 した結果, No. 2, No. 5, No. 8 は B. licheniformis, No. 3, No. 6, No. 9 は B. stearothermophilus であった. 著 者の一人はこれらのBacillus 属細菌は水ようかんの原 材料および製造工程における污染菌であることを明らか にしている9!，製造工程において Bacillus 属細菌に污染 された水ようかんでは加熱処理を行ってもこれらの一部 がなお生存し, 保存中に増殖して水ようかんの離水を生 成させるとともに包装容器内での縮み現象に関与してい ると考えられる.離水水ようかんから分離した上記 9 菌 株の Bacillus 属細菌の細胞懸濁液 $1 \mathrm{ml}\left(1.0 \times 10^{8} \mathrm{CFU} /\right.$

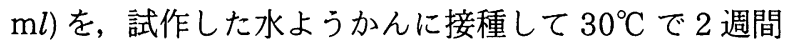
培養した場合に認められる離水生成の結果を Table 4 に示した。、いずれの菌株の場合にす離水は生成したが Bacillus 属菌株により離水率に顕著な差異が認められ
た.すなわち離水率 $30 \%$ 以上を示した水ようかんは No. 1 , No. 4, No. 7 でB. subtilis 菌体を接種したもので あった。

\section{4. 離水に及ぼす糖および微生物の影響}

離水の生成割合が使用した糖により大きく異なり, しょ糖を使用した水ようかんの場合，多量の離水が生じ ることを認めた。 そこで今回，離水に及ぼす糖原料の影 響を観察するため，しょ糖，グルコース，フラクトース およびマルトースを $30 \%$ 濃度でそれぞれ別個に使用し た小倉水ようかんを試作した。すなわち No.1. 分離株細 胞液 $1 \mathrm{ml}\left(1.0 \times 10^{8} \mathrm{CFU} / 1 \mathrm{ml}\right)$ を小倉水ようかん 1 カップ $(67 \mathrm{~g})$ 当たり接種して離水生成に及ぼす糖の影 響を検討した結果を Table 5 に示した。しょ糖を用いた 場合は対照が $5 \%$ であったのに対し $35 \%$ 之離水率は高 くなった. グルコース, フラクトース, マルトースを使 用した場合は，いずれも細菌細胞の接種の有無にかかわ らず離水率は 3〜 7\% で大きく変わらなかった。他方, しょ糖使用量を 0 50\% に変化させて上記と同条件で 分離 No. 1 株の細胞液接種, 粗酵素液, またはその加熱 粗酵素液を添加して水ようかんを試作した， $30^{\circ} \mathrm{C} ， 2$ 週 間保存後の離水生成状況を測定した結果を Fig. 1 に示 した．対照と加熱粗酵素液の場合はしょ糖濃度を 10〜 $50 \%$ に増加しても離水率は 3〜8\% と低く, 分離株細胞 液接種または粗酵素液を添加したものはしょ糖含量が増 加するほど離水率が高まり，しょ糖含量が $50 \%$ のとき には離水率はそれぞれ $45 ， 40 \%$ となった．このときの しょ糖の変化を測定した結果, いずれのしょ糖濃度む分 離株細胞液接種または粗酵素液の添加により著しく減少 し，その減少率は 85～94\% であった。 また対照または 加熱した粗酵素液を添加した場合の減少率は 15〜30\% であった。

5. 離水水ようかんより分離した B. subtilis No. 1 株 の生産する高分子糖類

以上の結果より, Bacillus 属細菌によるしょ糖の分 解・縮合反応が起きていると考えられる．そこで最む水 ようかんの離水に関与していると考えられる分離 $B$. subtilis No. 1 株の粗酵素液を用いて高分子糖類の生成 
Table 3. Characteristics of Bacillus spp. isolated from Mizu-yokan with syneresis

\begin{tabular}{|c|c|c|c|c|}
\hline & \multicolumn{3}{|c|}{ Strain No. of isolates } & \multirow{2}{*}{$\begin{array}{l}\text { B. subtilis } \\
\text { IFO } 3007\end{array}$} \\
\hline & 1 & 4 & 7 & \\
\hline \multicolumn{5}{|l|}{ Cell shape } \\
\hline shape & Rod & Rod & Rod & Rod \\
\hline length $(\mu \mathrm{m})$ & 0.8 & 0.8 & 0.8 & 0.8 \\
\hline Gram reaction & + & + & + & + \\
\hline Spore formation & + & + & + & + \\
\hline shape & $\mathrm{E}$ & $\mathrm{E}$ & $\mathrm{E}$ & $\mathrm{E}$ \\
\hline position & Center & Center & Center & Center \\
\hline swelling at sporulation & - & - & - & - \\
\hline Motility & + & + & + & + \\
\hline Catalase & + & + & + & + \\
\hline Anaerobic growth & - & - & - & - \\
\hline Voges-Proskauer broth & + & + & + & + \\
\hline $\mathrm{pH}$ in Voges-Proskauer broth & 5.5 & 5.3 & 5.6 & 5.5 \\
\hline Hydrolysis of casein & + & + & + & + \\
\hline gelatin & + & + & + & + \\
\hline starch & + & + & + & + \\
\hline Utilization of citrate & + & + & + & + \\
\hline propionate & - & - & - & - \\
\hline Formation of indole & - & - & - & - \\
\hline Egg-Yolk lecithinase & - & - & - & - \\
\hline Nitrate reduced to nitrite & + & + & + & + \\
\hline Growth at $\mathrm{pH} 6.8$ nutrient broth & + & + & + & + \\
\hline pH 5.7 nutrient broth & + & + & + & + \\
\hline Growth in $7 \% \mathrm{NaCl}$ & + & + & + & + \\
\hline Growth at $10^{\circ} \mathrm{C}$ & - & - & - & - \\
\hline $30^{\circ} \mathrm{C}$ & + & + & + & + \\
\hline $50^{\circ} \mathrm{C}$ & + & + & + & + \\
\hline $55^{\circ} \mathrm{C}$ & - & - & - & - \\
\hline Acid from D-glucose & + & + & + & + \\
\hline L-arabinose & + & + & + & + \\
\hline D-xylose & + & + & + & + \\
\hline D-mannitol & + & + & + & + \\
\hline Gas from glucose & - & - & - & - \\
\hline
\end{tabular}

+ : Positive, - : Negative, E: Ellipsoidal

Table 4. Syneresis of Ogura Mizu-yokan inoculated cells of each strain of Bacillus spp. isolated from Mizu-yokan with syneresis

\begin{tabular}{lcc}
\hline \multicolumn{1}{c}{$\begin{array}{c}\text { Strain No. of isolates } \\
\text { (Identified name) }\end{array}$} & \multicolumn{2}{c}{ Rate of syneresis (\%) } \\
\cline { 2 - 3 } & Mizu-yokan & Mizu-yokan inoculaed Bacillus cells \\
\hline No. 1 (B. subtilis) & 5 & 40 \\
No. 2 (B. licheniformis) & 3 & 20 \\
No. 3 (B. stearothermophilus) & 5 & 23 \\
No. 4 (B. subtilis) & 4 & 45 \\
No. 5 (B. licheniformis) & 5 & 22 \\
No. 6 (B. stearothermophilus) & 3 & 25 \\
No. 7 (B. subtilis) & 5 & 38 \\
No. 8 (B. licheniformis) & 3 & 20 \\
No. 9 (B. stearothemophilus) & 4 & 23 \\
\hline
\end{tabular}

One $\mathrm{m} l\left(1.0 \times 10^{8} \mathrm{CFU} / \mathrm{ml}\right)$ of each strain isolated from Mizu-yokan with syneresis was inoculated to $67 \mathrm{~g}$ of pasteurized Ogura Mizu-yokan in a cup and the rates of syneresis were estimated after incubation at $30^{\circ} \mathrm{C}$ for 14 days.

について検討した，透析チューブ内で生成した高分子糖 類を材料および方法の項で記した方法で調製・同定を 行った，凍結乾燥品は無色透明で，還元性はなく冷水に 易溶で，65\%エタノールに不溶であった．これらの高分 子糖類を $0.1 \mathrm{~N}$ 硫酸, $60^{\circ} \mathrm{C}$ で 60 分間加水分解後に薄層
クロマトグラフィーを行うといずれも原点のスポットは 消失し，単一のスポットのみが認められた。この高分子 糖類の加水分解液む還元糖をフラクトースとして測定す ると分解に用いた高分子糖類とほぼ等しい重量のフラク トースが検出された．加水分解液のセリワノフ反応 ${ }^{15}$ は 
Table 5. Effect of saccharide of Ogura Mizu-yokan on syneresis by B. subtilis No. 1

\begin{tabular}{lcc}
\hline & \multicolumn{2}{c}{ Rate of syneresis (\%) } \\
\cline { 2 - 3 } Saccharide & Mizu-yokan & Mizu-yokan inoculated B. subtilis No. 1 cells \\
\hline None & 3 & 4 \\
Sucrose & 5 & 40 \\
Glucose & 3 & 7 \\
Fructose & 5 & 6 \\
Maltose & 4 & 7 \\
\hline
\end{tabular}

One $\mathrm{m} l\left(1.0 \times 10^{8} \mathrm{CFU} / \mathrm{m} l\right)$ of cell suspension of $B$. subtilis No. 1 isolated from the Ogura Mizu-yokan with syneresis was inoculated to Ogura Mizu-yokan containing $30 \%$ of each saccharide and the rates of syneresis were estimated after incubation at $30^{\circ} \mathrm{C}$ for 14 days.

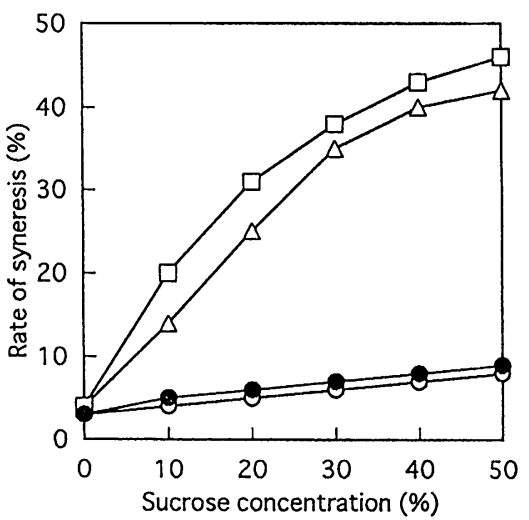

Fig. 1. Effect of sucrose concentration on rate of syneresis of Mizu-yokan (Soft bean jam) inoculated cells of $B$. subtilis No. 1 strain isolated from Mizu-yokan with syneresis Ogura Mizu-yokan (Soft azuku bean jam) were incubated with no addition of saccharide (O), the cells of $B$. subtilis No. 1 strain $(\triangle)$, cultural broth of $B$. subtilis No. 1 exclud. ed the cells by membrane filter $(\square)$, and the heated cultural broth $(-)$, respectively at $30^{\circ} \mathrm{C}$ for 14 days.

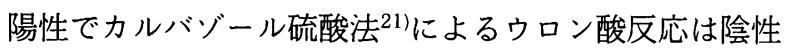
であった．ペーパークロマトグラフィーでの成分はフラ クトースと $R f$ 值が一致するスポット以外は認められな かった。 また分解物は，フラクトースの赤外部吸収スぺ クトル, 混融試験の結果と一致し, この点からも構成成 分はフラクトースのみと確認された。 これらの高分子糖 類とイヌリンをそれぞれアセチル化し, 前後の赤外部吸 収スペクトルを測定すると, 両者は非常によく似た吸収 曲線を示した．しかし両者をアセチル化し，その前後の 旋光度を測定するといずれもアセチル化前は (一)の值 であった. しかしアセチル化後は高分子糖類の旋光度は (+)の值に変化したが，イヌリンは (一)のままであっ た. 以上のことより，これらの高分子糖類はフレイン型 の構造をむつレバンであると判断された ${ }^{17)}$. また同様の 方法でレバンは $30 \%$ 以上の離水率を示した水ようかん および離水液から検出された。

\section{考 察}

水ようかんの離水とは固形物と溶液に分離することを
いい,この現象はゲルの離水といわれるものである，離 水は水ようかんのみならずジャム，ゼリー，クリーム， 生あん, 固形食品の缶詰などゲル状食品に一般に見られ る.これはまた熱力学的には不安定なゲルから安定なゲ ルへの移行と考えられる ${ }^{16)}$. 離水率 $20 \%$ 以上の水よう かんの特徴は, 本来, しょ糖が 98.5 99\%のものが 7 $10.5 \%$ と著しく少なく，グルコースが $0.2 \sim 0.5 \%$ のも のが 40.3〜 45.7\% と著しく多いことである.この原因 は水ようかん中に残存するBacillus 属細菌増殖に伴い 生産される酵素によりしょ糖が変化したものと考えられ る. しょ糖は水を吸収し, 保水力が高いためしょ糖濃度 の高い水ようかんほど離水は少ない. しょ糖の $20^{\circ} \mathrm{C}$ に おける溶解度は $67.1 \%$ であるのに対しグルコースのそ れは $49.7 \%$ である ${ }^{4)}$. またしょ糖は過飽和の溶液を作り やすく ${ }^{14)}$ ，水ようかん中では水分子を砂糖分子の方に固 定して吸水物質として働き，あんでんぷんを $\alpha$-でんぷん に保って老化による離水を防止している ${ }^{12)}$. また離水率 $20 \%$ 以上の水ようかんの内部には高分子糖であるレバ ンが確認された。 レバンはしょ糖とラフィノースから作 られる細菌性多糖類して知られ ${ }^{17)}$, B. subtilis ${ }^{1)}, B$. polymyxa $a^{8)}$ など液体培地においてその生成が報告さ れている. この場合炭素源としてはしょ糖が用いられ, 菌体内外に生産される. また, 水ようかん中の Bacillus 属細菌により生成されたレバンは水溶性で離水液中に溶 解して水ようかんの水分を吸収し, さらに離水を進行さ せるあのと考えられる. B. subtilis は, しょ糖からグル コースとレバンを生成するレバンスクラーゼ19)のほか に, あん中に存在するでんぷんやその分解物としょ糖か らマルトース, マルトトリオースを生成するところから $\alpha$-グルコシダーゼ20)の酵素む同時に生産していると考え られる。レバンスクラーゼはしょ糖を分解して $\beta-2,6$ 結 合の高分子フラクタンであるレバンを合成する酵素であ るが, 受容体としてフラクトース以外の糖の存在下, しょ糖に作用させると受容体分子の $\mathrm{C} 1$ 位の水酸基に選 択的にフラクトシル基を転移させ，非還元性のへテロオ リゴ糖を生産することが知られている2,6). 本実験にお いても B. subtilis No. 1 株の接種やその粗酵素液の添加 により $20 \%$ 以上の離水が生成するのは，いずれもしょ 糖が含まれている系のみであり, また初発しょ糖含量が 
高いほど離水率が高まった。

Hestrin ら5) がB. subtilis およびAerobacter levanicum について $(n+m)$ aldose-D-fructofuranoside $+(n)$ $\mathrm{H}_{2} \mathrm{O} \rightarrow(n+m)$ aldose $+(n)$ D-fructose + levan の式を発表 し，消費されたしょ糖は生成されたグルコース，フラク トースなどの還元糖とレバンの和に相当するとした．水 ようかん中では B. subtilis No. 1 株などによりしょ糖か らグルコース，フラクトースおよびレバンが生産されて 蓄積され，しょ糖とグルコース，フラクトースおよびレ バンの水分保持力の差異により離水が進行したものと思 われる。

\section{要 約}

1. $20 \%$ 以上の離水を生じた水分含量 43 ～54\%の 湯殺菌水ようかんから，いずれす $1.1 \times 10^{5} \sim 3.6 \times 10^{6}$ $\mathrm{CFU} / \mathrm{ml}$ の Bacillus 属細菌が検出された. 5\% 以下の 離水率のものの Bacillus 属細菌はいずれも $300 \mathrm{CFU/}$ $\mathrm{m} l$ 以下であった.

2. 離水した湯殺菌水ようかんから Bacillus 属細菌 の分離・同定を行った. 分離数は圧倒的に B. subtilis が 多く, 次いで B. licheniformis 之 B. stearothermophilus であった。

3. $20 \%$ 以上の離水は Bacillus 属細菌の増殖により 引き起こされた。すなわち同細菌が生産する酵素がしょ 糖の分解や縮重合を引き起こしてグルコース，フラク トース, マルトース, マルトトリオースおよびレバンを 生産させ，しょ糖の抱水を解除したことによることが示 唆された。

\section{文献}

1) Challinor, S. W., Haworth, W. N. and Hirst, E. L.: The constitution and chain lengths of levan. J. Chem. Soc., 676-679 (1934).

2) Feingold, D. S., Avigad, G. and Hestrin, S.: Enzymatic synthesis and reaction of a sucrose isomer $\alpha$-Dgalactopyranosyl- $\beta$-D-fuructofuranoside. J. Biol. Chem., 224, 295-307 (1957).

3）長谷川武治編：改訂版微生物の分離と同定. p. 99-153, 学会出版センター, 東京 (1985). 4）浜口栄次郎，桜井芳人：シュガーハンドブック．p. 785, 朝倉書店, 東京 (1964).

5) Hestrin, S., Aavineri-Shariro and Ashner, M.: The Enzymic production of levan. Biochem. J., 37, 450456 (1943).

6) Hestrin, S., Feingold, D. S. and Avigad, G.: Synthesis of sucrose and other $\beta$-D-fuructofuranosyl aldosides by levansucrase. J. Am. Chem. Soc., 77, 6710 (1955).

7) Lyne, R. R., Peat, S. and Stacey, M.: The constitution of certain levans formed by bacterial action. J. Chem. Soc., 237-241 (1940).

8) Murphy, D.: Structure of a levan produced by Bacillus polymyxa. Can. J. Chem., 30, 872-878 (1952).

9) 内藤茂三：水ようかんの微生物变敗とオゾン殺菌につい て. 包装研究, 8(2), 15-29 (1988).

10）内藤茂三，塚本 忠：製あん工程の微生物菌数に及ぼす オゾン処理の影響. 愛知食品工試年報, $30,68-83$ (1989).

11）永原太郎，岩尾裕之，久保彰治：全訂食品分析法. p. 121-123, 柴田書店, 東京 (1991).

12）二国二郎，不破英次，辰巳ちえ： $\beta$-澱粉化に及ぼす蔗糖の 影響. 農化, 23, 90-91 (1949).

13）日本食品工業学会, 食品分析法編集委員会編：食品分析 法. p. 47, p. 102-103, p. 128-133, p. 241-246, 光琳, 東 京 (1982).

14) 日本女子大学食物学教室編：調理科学. p. 13, 朝倉書店, 東京 (1974).

15）小原哲二郎：食品分析ハンドブック．p. 192, 建白社 (1973).

16) 理化学辞典第 2 版. p. 599, 岩波書店, 東京 (1955).

17）左右田徳郎, 江上不二夫：多糖類化学. p. 189-679, 共立 出版, 東京 (1955).

18) Sneath, P. A., Mair, N. S., Sharpe, M. E. and Hort, J. G.: Bergey's Manual of Systematic Bacteriology, Vol. 2. p. 1105-1139, Williams and Wilkins Co., Baltimore, London, Los Angeles, Sydney (1986).

19) Tanaka, T., Yamamoto, S., Oi, S. and Yamamoto, T. Structures of heterooligosaccharides synthesized by levansucrase. J. Biochem., 90, 521-526 (1981).

20) 千葉雅哉, 下村得治: $\alpha$-グルコシダーゼの糖転移作用. 澱 粉科学, 26, 59-67 (1979).

21) 瓜谷郁三, 駒野 徹, 志村憲助, 中村道徳, 船津 勝: 生 物化学実験法 1, 還元糖の定量法. p. 9-11, p. 50-52, p. 60-64, p. 109-111, 学会出版センター, 東京 (1990). 